\title{
Cosmopolitanism in the Arab World
}

\section{Developments, Continuities and Changes since the Arab Spring}

\author{
Heba Elsayed \\ Independent Scholar, Leeds, UK \\ elsayed.h85@gmail.com
}

\author{
Adam K. Webb \\ Hopkins-Nanjing Centre, Johns Hopkins University School \\ of Advanced International Studies, Nanjing, China \\ adamkwebb@jhu.edu
}

\section{Introduction}

As the Arab spring movements burst forth in 2011 in Tunis, Cairo, Damascus and elsewhere, the tensions in this wave of activism quickly became apparent. Amid prevailing analyses, one approach focused on an internet-savvy generation of young activists, often of middle-class extraction. Their demands began with political democracy and the dismantling of corrupt dictatorships. The horizons of these activists were seen as extending to the leftist global justice and 'Occupy' movements elsewhere in the world. Another approach focused on the release of more traditionalist energies from below, among those at odds with secular globalization. The latter bloc was seen as tapping into Islamist resistance movements that had defied repression for over two generations throughout the Muslim world.

Once the heady enthusiasm and broad-based protests of the early days gave way to counter-coups and civil war, these images of the driving social forces of the Arab spring became darker and more complicated. Grievances and aspirations on the ground were both more diverse and more ambivalent than any projection made by outside observers, or any frame constructed by activists on the street or social media. A recurring controversy, however, has hinged on whether recent events in the region, culminating in the Arab spring, can be seen, overall, as a cosmopolitan (Leichtman and Schulz 2012; Webb 2014) or an anti-cosmopolitan trend (Traub 2014; Zubaida 2010). On the one hand, the various movements that arose during this latest period of Arab revolt have res- 
onated and involved some points of collaboration across borders, both within and beyond the Arab Middle East. Compared to earlier eras, this wave of revolts finds the global public sphere mattering more both as audience and as sources of inspiration. On the other hand, certain social forces that asserted themselves through demonstrations, ballot boxes, arms and some repressive clampdowns, have an air of insularity and retreat.

In any case, these competing pulls on the spectrum of cosmopolitanism cannot be understood only as a snapshot of opinion and practice in the last few years. They have historical forerunners and referents. Some can be traced to premodern events. Archibald Lewis called the Islamic world 'the great intermediary civilization of medieval times' (Lewis 1988: 27-28), with influence and inspiration flowing across its frontiers with the other zones of Eurasia and Africa. Marshall Hodgson also noted the 'cultural gradient' (Hodgson 1974: vol. 2,539 ) that drew intellectual and spiritual energy into this vast cosmopolitan space. As in other civilizations, the premodern Islamic world was characterized by complex layers and scales of identity. Many of the markers of engaging with the widest horizons - whether cultural, religious or structural — were concentrated in the higher echelons. Over the centuries, a tension also persisted between those who saw those horizons as the frontiers of their own civilization, with cosmopolitanism limited to a space of common identity, and those who saw a more permeable boundary with other traditions.

These tensions over the scope, sources, bearers and content of cosmopolitanism took on new form with the rise of European influence over the Middle East. Starting with Napoleon's foray into Egypt and the slow unraveling of the Ottoman Empire, the cultural gradients shifted. In terms of education, political discourse and lifestyle, emerging new elites were often oriented more toward francophone and anglophone networks than to the lower classes of their own societies. Indeed, European colonial influence marked what many have referred to as a 'golden era' representing the height of cosmopolitanism in the Arab region, albeit one centered around limited elite circles and involving liberal practices such as alcohol consumption (Zubaida 1999; Meijer 1999). Nevertheless, in the decades after World War II, uneven oil-based prosperity, the pressures of the Cold War, pan-Arab nationalism and the resurgence of political Islam all buffeted cosmopolitan aspirations in varying directions.

Many theoretical attempts to make sense of this landscape have gravitated to a binary contrast between the Western and the Arab. The West is seen as either the main source of modern cosmopolitan sensibilities, given its prosperity, openness and tolerance, in contrast to 'backward' Arab and Islamic parochialisms; or as a colonialist or imperialist, and thus alien, influence that can only be countered by a recovery or construction of a distinct universalism in the region, 
one based on some variant of Arab nationalism or Islamic authenticity. More recent efforts have tried to go beyond this simplistic binary—and its rather fixed view of identities in the Arab world - to consider new networks and social practices on the ground more carefully, and to develop a more nuanced and contextualized understanding of cultural, political and economic patterns in everyday Arab life (Achcar 2013). For example, according to Bayat (2009), the disadvantaged quarters of Arab cities reveal, amid repression and inequality, a range of intense cosmopolitan interactions. Emigration to the Gulf over the last generation has opened up new, non-western paths of cosmopolitanism (Ghannam 2006). Even within the same society, cosmopolitanism can vary greatly between classes (Elsayed 2016; Schielke 2012). Recently, more attention has been paid to the intersection of cosmopolitan influences, such as from western middle-class lifestyles and gendered local codes of morality (Sabry 2010; de Koning 2009; Kraidy 2005).

The recent tumult of the Arab spring has further illuminated this landscape. It has signaled a new economic, social and political turn in contemporary Arab history, and brought about a mix of optimism and foreboding regarding the fate of cosmopolitanism in the region. The eruption of new kinds of activism and practices suggests new types of cosmopolitanism, less dependent on the western metropoles and more driven by local experiences on the ground (Underwood 2012). While previously the West loomed large in the Global South, the Arab spring has offered a new epicenter with regional and global implications.

This special issue takes advantage of the opportunity that the Arab spring has opened for a renewed conversation about what cosmopolitanism means in the region. Rather than lingering in the past and 'grieving' an Arab cosmopolitanism that once was (Hanley 2008), we are interested in what is, in making sense of the present moment in a perspective that cuts across time and space. Recent events have seen the eruption of different forms of cosmopolitanism, forms that must be understood in relation to changing social patterns and self-understandings, and in the way personal aspirations play out amid the turmoil and frustrations of public events. In what way has the Arab spring catalyzed new types of cosmopolitanism? Are new centers of Arab cosmopolitanism now emerging? Can we identify continuities and innovations in relation to older forms of cosmopolitanism in the region? How have recent patterns of migration and exile led to a rethinking of inside, outside and belonging? How are these aspirations experienced differently by different social strata? What mechanisms of communication underpin these diverse emerging cosmopolitanisms? The articles here represent a wide range of approaches to these themes and explore rich case studies. 
Noureddin Mahmoud Zaamout explores the fleeting emergence, in the early Arab spring, of 'Syrianism', which he identifies as the orientation of a broad opposition movement. He argues that it drew on the rich background of medieval and Ottoman 'cosmopolitan hubs', and on Syria's longstanding religious and ethnic diversity. The Arab spring included a Syrianist challenge to the distorting frames of colonial and nationalist state building projects. The spontaneity and breadth of the early protest movement gave way to divisions among the forces of Assad's repression, Islamists and Kurdish nationalists. These multiple competing identities were each exclusionary in their own way, even as each was also linked to its own type of transnational circuit in a 'global proxy war'. Despite this mostly dark picture of cosmopolitanism being overshadowed by events, the account of Syrianism holds out hope for its recovery and influence during Syria's eventual reconstruction.

While Zaamout's exploration deals with competing versions of national identity, the next two articles shift the focus to class, in the broad sense. Liina Mustonen draws on fieldwork in Cairo to understand the interweaving of nostalgia and cosmopolitanism among the upscale women of a Cairo cultural association. Their nostalgia for the period from the late Ottoman era to the early 1950s portrays that past as a time of ethnic and religious diversity, and as an international outlook that only fully survives in a specific and very limited layer of contemporary Egyptian society. By contrast, such nostalgia also serves to indict the upsurge of Islamist and other apparently non-cosmopolitan tendencies in the Egypt of the Arab spring. Mustonen details the class barriers, ranging from attire to cultural capital to language, that divide the cultural association's cosmopolitan space from much of Egyptian society.

Rayya El-Zein's study of cafes, bars and clubs in the Levant addresses the question of class and cosmopolitanism from a different angle. Whereas in Mustonen's article, class difference is bound up with time and nostalgia, for ElZein it reflects generational divides and the gentrification of certain spaces. Fieldwork in Ramallah, Beirut and Amman reveals a young, gentrified cosmopolitanism that colors the 'artsy', 'gritty' venues of music, poetry readings and the like. For the twenty- and thirty-somethings who populate such settings, creativity centers on the social rather than the political. This current is more casual than the older elite cultures, but also polices entry to its spaces based on distinct norms influenced by the West, yet peculiar to its variant of youth, or shabab culture. This culture comes into tension with an 'Other' in the less upscale (especially male) youth, whose participation is more carefully screened. The latter offer their own shabab cosmopolitanism of a different sort, and thus imply a critique of how the creative provocation by young, gentrified cosmopolitans is still embedded in structures of consumer capitalism. 
The next two articles consider cosmopolitanism in media. Fadi Haddad examines a fictional context: the depiction in a Dubai-based television serial of four young men, not unlike the gentrifiers of the Levant, who live amid the prosperity and relative calm of the Gulf. Much like al-Jazeera, pan-Arab television has gained a huge audience through satellite technology, just as the largely expat demographic of a weal thy city like Dubai is the product of regional migration. The television serial brings the two phenomena together by showcasing everyday cosmopolitanism. Technology and migration displace spatial boundaries in favor of other markers. Haddad's scrutiny of the drama reveals that cultural proximity still offers important common ground, despite many superficially placeless markers of globalized prosperity, such as the characters' dress and jobs. Amid the cosmopolitanism of the setting and the media universe, some soft boundaries around an Arab identity persist.

The last article, by Josepha Ivanka Wessels, deals with a different type of media - documentary films - and a more widespread diaspora. She shows how technological innovations in digital and social media and satellite diffusion have made possible a more genuinely global audience for documentaries, an audience that radiates from the global film festivals in northwestern Europe that are attended by a new generation of Arab filmmakers. Against the background of post-1970s Palestinian exile filmmaking, this new generation shifts to the story of new voices, including those of migrant workers and women. In addition, the emphasis has moved from political revolution to more personal experiences of resilience and defiance amid the repression, carnage and displacement of the Arab spring's worst conflicts. In a construction of 'global citizenship', these depictions resonate with audiences in the West and elsewhere. They elicit moral outrage that brings to light novelties as well as continuities with an earlier era of universalistic sympathies.

The varied perspectives reflected in these contributions confirm that the Arab spring was more than an outcry against a set of long existing repressive regimes. Indeed, it went beyond an immediate confrontation with the state; it was more than protests, mass disruptions and death. It was also concerned with the birth of hope, new connections, aspirations, the spread of new cosmopolitan values and the prevalence of alternative ways for Arabs to see themselves and be seen by the world. These new thoughts and aspirations extended throughout the whole region, transcending any immediate physical borders or sites of protest. For this reason, this edition seeks a broad understanding of the Arab spring. While including the countries where protests were rife (Egypt, Syria) it also looks at cities where revolutions did not occur, yet which were influenced by the political, economic and cultural shockwaves emanating from the uprisings. Haddad, for example, focuses on Dubai and the migration of Arab 
citizens from nearby affected Arab cities to this new hub of Arab cosmopolitanism. Wessels focuses even further geographically, by arguing that universal values of loss and grievance allowed Arab filmmakers from post-uprising wartorn Arab countries to form links with their peers and audiences outside the region, in Europe and often beyond. Through her focus on three capital cities of the Levant-Ramallah, Beirut and Amman-El Zein's work is important in helping us understand the longer-term aftermath of the Arab spring, especially in relation to youth identities. El Zein argues that politics manifests itself beyond the short-lived spectacle of protests or the sites of civil unrest. This is especially true, given that the Arab protests and the celebratory assessments of them have yet to provide any substantive change of the type protesters sought. A focus on the three cities El Zein examines reveals how spaces of leisure chosen by the younger generation harbor a middle-class counterculture involving contestation over competing cosmopolitan identities. By moving away from conventional (usually western) theories that reduce such alternative youth spaces to simplified acts of 'freedom', we can begin to see them, in all their complexities and contradictions, as ongoing sites of daily social and political struggle.

Several themes cut across all these contributions: cosmopolitan potential and its ebb and flow over time; the bearers of the more cosmopolitan identities and aspirations - who they are and how they are contributing to and affected by this moment of the Arab spring; and, not least, whether the Arab spring is an expression of, or a backlash against, such wider horizons. Any account of cosmopolitanism in this context must tackle questions of layering and scale.

To ask about layers is to interrogate assumptions about how broader horizons are correlated with structural position. As these cases illustrate, however, the realities have become more complex than the age-old pattern in which cosmopolitanism is thought to be displayed mainly by those with power and wealth. Technology makes the cosmopolitan more accessible to less advantaged strata. How a given layer of society frames its own cosmopolitanism in contrast to other layers has become more complex. One may draw boundaries to preserve privilege, or to protect spaces of experimentation with new norms, or perhaps merely out of indifference or as a retreat into one or another niche in a more fragmented and fluid late modern world.

To ask about scale is to weigh whether new technological and demographic possibilities mean the dispersion or overriding of older cultural identities, or merely their affirmation in new forms. The Arab identity of a century ago, or of the pan-Arab post-war nationalisms, may well be a different phenomenon now, when it flashes across the screens of European film festivals and satellite broadcasts from the Gulf. The ease of movement, interactions and the scale of 
the audience have shifted greatly, even as some assumptions about one's reference groups and natural interlocutors may linger. In the more diverse circuits of globalization, what one connects to abroad when one looks outward also varies. As the Syrian civil war has shown - as did the Spanish civil war threequarters of a century earlier-actors locked in a struggle with one another may each have cosmopolitan networks and worldviews.

Of course, the verdict on all of these questions will probably not be apparent for another generation. Even on the surface, the political events of the Arab spring have not run their course. As a wave of protest and imagination and aspiration, if it is anything like earlier waves, its impact and meaning will likely take a long time to come into sharper view. The trauma of carnage and repression also molds the identities of those born into it and and those whose formative years overlap with it. Finally, the attention these authors pay to practices in daily life-to rooted cosmopolitanism - also reminds us that the evolving substrate of society may matter much more in the long run than what makes the headlines. Their accounts thus not only offer us a snapshot of how a world historical moment is being experienced and imagined; they also suggest factors that are likely to shape the trajectory of the region and its engagement with the rest of the world for decades to come.

\section{References}

Achcar, Gilbert (2013). The People Want: A Radical Exploration of the Arab Uprising. California and London: University of California Press.

Bayat, Asef (2009). Life as Politics: How Ordinary People Change the Middle East. Stanford, CA: Stanford University Press.

de Koning, Anouk (2009). Global Dreams: Class, Gender, and Public Space in Cosmopolitan Cairo. Cairo and New York: American University in Cairo Press.

Elsayed, Heba (2016). Mediated Imagination, Class and Cairo's Young Cosmopolitans. In Tarik Sabry and Layal Ftouni (eds.), Arab Subcultures: Transformations in Theory and Practice, pp. 152-176. London and New York: Ів Tauris.

Ghannam, Farha (2006). Keeping Him Connected: Globalization and the Production of Locality in Cairo. In Diane Singerman and Paul Ammar (eds.), Cairo Cosmopolitan:Politics, Culture, and Urban Space in the New Globalized Middle East, pp. 251-268. Cairo and New York: American University in Cairo Press.

Hanley, Will (2008). Grieving Cosmopolitanism in Middle East Studies. History Compass 6 (5): 1346-1367.

Hodgson, Marshall G.S. (1974). The Venture of Islam: Conscience and History in a World Civilisation. 3 vols. Chicago: University of Chicago Press. 
Kraidy, Marwan (2005). Hybridity: The Cultural Logic of Globalization. Philadelphia: Temple University Press.

Leichtman, Mara A. and Dorothea Schulz (2012). Introduction to Special Issue: Muslim Cosmopolitanism: Movement, Identity and Contemporary Reconfigurations. City \& Society $24(1): 1-6$.

Lewis, Archibald R. (1988). Nomads and Crusaders, AD 10oo-1368. Bloomington: Indiana University Press

Meijer, Roel (1999). Introduction. In Roel Meijer (ed.), Cosmopolitanism, Identity and Authenticity in the Middle East, pp. 1-14. Oxon and New York: Routledge.

Sabry, Tarik (2010). Cultural Encounters in the Arab World: On Media, the Modern and Everyday Life. London and New York: I.B. Tauris.

Schielke, Samuli (2012). Surfaces of Longing. Cosmopolitan Aspiration and Frustration in Egypt. City \& Society 24 (1): 29-37.

Traub, James (2014). The Lighthouse Dims. Foreign Policy. Accessed 1o November 2017: https://foreignpolicy.com/2014/12/23/lighthouse-dims-egypt-alexandria -salafists-mubarak-sisi-longform/. 23 December 2014.

Underwood, Lori (2012). Cosmopolitanism and the Arab Spring: Foundations for the Decline of Terrorism. New York: Peter Lang Publishing.

Webb, Adam K. (2014). The Rise of the Cosmopolitan Traditionalists: From the Arab Spring to a Global Countermovement? International Political Science Review 36 (4): 425-440.

Zubaida, Sami (1999). Cosmopolitanism and the Middle East. In Roel Meijer (ed.), Cosmopolitanism, Identity and Authenticity in the Middle East, pp. 15-34. Oxon and New York: Routledge.

Zubaida, Sami (2010). Cosmopolitan Citizenship in the Middle East. Open Democracy. Accessed 15 July 2016: https://www.opendemocracy.net/en/cosmopolitan -citizenship-in-middle-east/. 2o July 2010. 